\title{
A Study on the Magnitude and Causes of Turnover among Academic Staffs of Ethiopian Higher Institutions: Evidence from Ambo University
}

\author{
Motuma Hirpassa Minda*
}

\author{
College of Social Sciences, Ambo University, Post Box No: 19, Ambo, Ethiopia
}

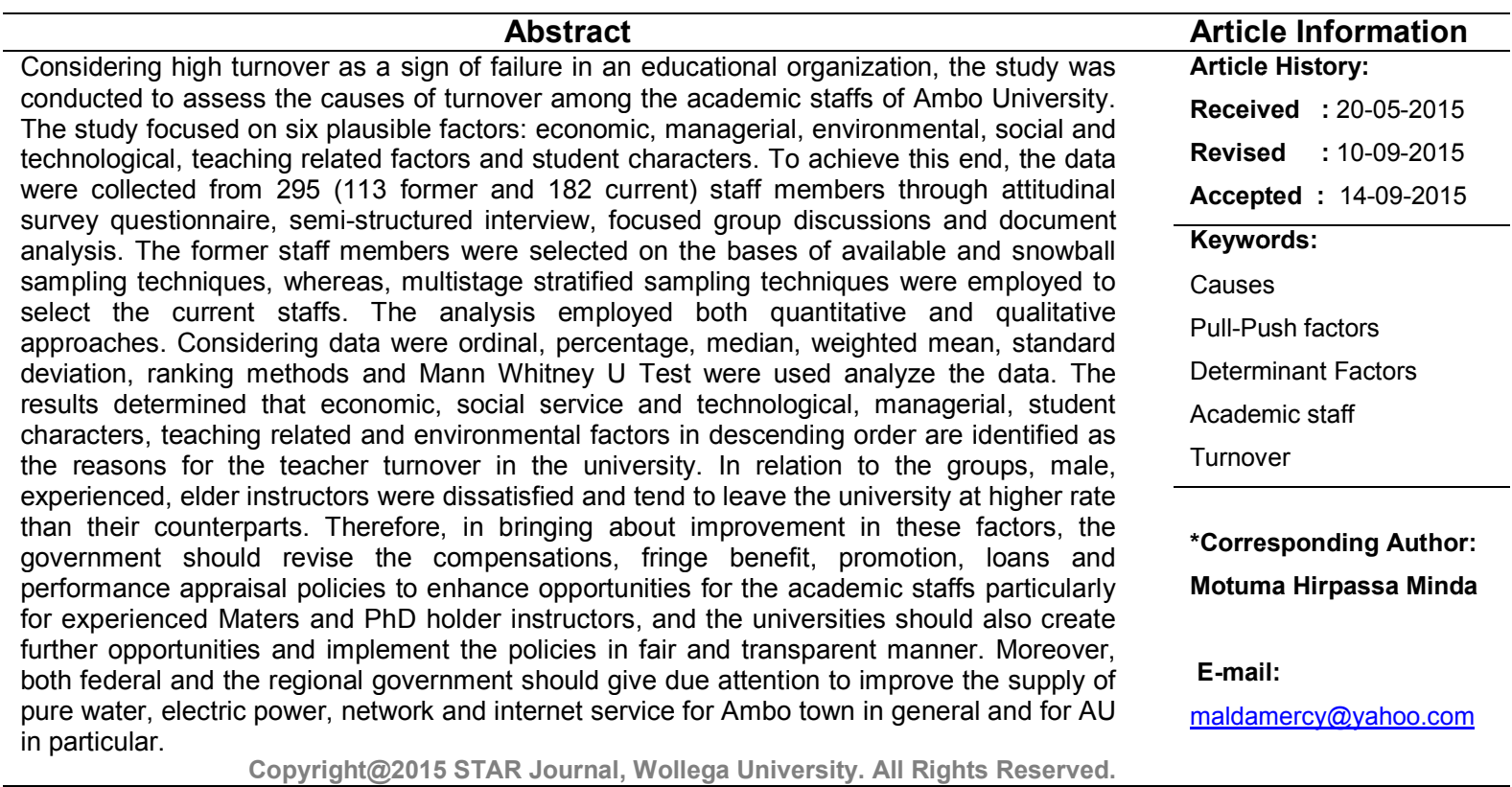

\section{INTRODUCTION}

The problems of employee separation have globally been recognized as a great worry for the organizational system (Hill and Hirshberg, 2013; Kainth, 2010 and Belkin, 2013). Trends around the world show that nearly all countries have experienced teacher separation from their educational systems. For instance, in America the maximum teacher dropout exceeded $80 \%$ in 1963 but the trends of turnover were changed after some 13 years by 1976; and excess of teachers in the country needed attrition to eliminate the surplus of teachers (Ellenburg, 1979). This shows that though turnover is avoidable in developed countries, it has continued increasing in developing countries. For example, the turnover rate reached $42 \%$ in Ivory Coast, two-fifth of the teachers in Zaire, and $46.6 \%$ in Ghana (Bame, 1991). Trend of teacher turnover has also been an age-old problem in the Ethiopian context beginning from the introduction of modern education in 1908 up to the present (Seyoum, 1992). To be specific, $67 \%$ of elementary school teacher in $1953,42 \%$ of the community teachers training finishers and $28 \%$ of the one-year in 1960 (Akililu, 1967:28) and
$17 \%$ of Oromia secondary school teachers turnover in 2006 (Motuma, 2006) were reported.

Different researchers use different terms: separation (Gomez-Mejia, 2003), turnover (Hill and Hirshberg, 2013 and Meyer, 2013), attrition (Victor, Pistose and Machaisa, 2012) and migration (Ghafffari and Singh, 2000) for the loss of human asset. Locally, Akililu (1967); Darge (2002); Seyoum (1992) (Getachew (1999); Manna and Tesfaye (2000) and Tesfaye and Demewoz (2004) used the terms interchangeably for this matter. However, literature shows the conceptual differences between these terms. Turnover (voluntary/involuntary or avoidable/unavoidable) is a broader term and process in which employees leave the organization and have to be replaced (Ghafffari and Singh, 2000). Attrition, on the other hand, is relatively a narrower term that used as an employment policy (Gomez-Mejia and other, 2003) designed to control a surplus of employees in an organization pushing only the employees to voluntarily and normally leave ((Brinson, 2010). Migration refers to teacher movement from one type of schools to another type of school (Bhatt, 2005). Similarly, dropout refers to wastage (Manna and Tesfaye, 


\section{Motuma Hirpassa Minda}

2000 and Tesfaye and Demewoz, 2004) and brain drain is a figurative term (Darge, 2002; Getachew 1999) that refers to any substantial movements of teachers from one local or field of work for different pushing factors to another for its pulling factors that offers greater attraction or rewards (Guzuma, 2012). Therefore, the broader term, turnover is used in this study to imply the importance of employee retention as well as pulling and pushing factors.

In this vein of study, different literatures have both globally and locally identified different factors, which can push instructors to leave their universities. Globally, Ellenburg, (1979) claims that out of a list of seventeen reasons the one given most frequently was salary, followed by teaching loads, inadequate supervision, poor assignment during first year at teaching, discipline problems, marriage and inadequate preparation in the subject filed. Ellenburg, (1979) generally concluded that administration is a key in teachers moral. That means, the more democratic the administration, the higher the moral and the reverse is also true. Other studies show that teachers' turnover can either be the response to low morale or reaction to stress or consequence of job dissatisfaction (Masahudu, 2008); lack of motivation and low job satisfaction (Paulse, 2005); lack of competencies for the profession; lack of initial preference and commitment to the profession or reaction to conflict or the consequence of the combination of some or all of the problems (Smith and Rowley, 2005).

Local studies have also shown that the employment conditions are more stressful than factors intrinsic to teaching (Darge, 2002 and Getachew, 1999). Among these, ineffective administration, low professional recognition, poor working condition, low salary and uncertainty about job security are found to be the major sources of teachers stress (Seyoum, 1992 and Manna and Tesfaye, 2000). Moreover, lack of economic incentives teachers' career commitment, perceived social status, supervision and professional support, initial preference of teaching and gender were found to be the major predictors of teachers' career decision (Tesfaye and Demewoz, 2004). Darge (Manna and Tesfaye, 2000) also determined that low income opportunities (including advancement and fringe benefits), students' character, performance evaluation, time pressure, resources (including books and facilities), regulation and social relationship in descending order, are the major sources for teachers' stress in other site.

In regard to the reasonable level of turnover, there are different arguments that can be made both against and in favor of a certain amount of staff turnover, each of which is equally persuasive (Torrington, 2005). The purpose of the first argument is in favor of the need for more dynamic employees with fresh blood to bring new ideas and experiences as well as to control over labor costs avoiding poor performers from time to time. The second argument focuses on the importance of instructors retention results from a poorly managed organization. However, to come up with a reasonable level of turnover, an organization should often set an average or a range of standard (Ghaffari and Singh, 2000). A goal might be to keep turnover to a level no higher than the preset standard for the organization. However, there are times when a goal of $0 \%$ turnover is a recipe for disappointment because turnover is inevitable for an organization. According to Taylor (1998) and Guzma (2012), turnover in excess of
Sci. Technol. Arts Res. J., July-Sep 2015, 4(3): 285-293

$5 \%$ has more negative consequences for educational organizations because substitution to cover the gaps created by turnover is challenging.

Whatever the level and reason is, acceptable or unacceptable, it is beneficial to know what loss is occurring on Ambo university's operations as a result of academic staff turnover because an unexpectedly high turnover has definite implications both on personal and organizational aspects.

Excessive turnover affect the morale of the remaining teachers and the university itself in general. Supporting this, Meyer (2013) writes that: "Turnover is something easy to overlook and yet it can make a school stand ahead of the rest." Lower morale, in turn, affects more than just the productivity and students' achievement particularly in education system (Killian, 1976). GomezMejia (2003) also justify that the loss of talented key personnel cripples the morale of the organization and other workers in the organization, which in turn, causes separation of employees in bunches; 'one triggering others. As the result, technological and educational development will be at risk and put other sectors into risks by retarding their development due to operational disruptions (Meyer, 2013). Moreover, the country's hopes of development at large will be darkening (Pennington and Edward, 2000). Claiming this, MOE has stated the following justification:

We are losing our talent and highly skilled human resource, for each of whom we have paid dearly. Therefore, we must develop mechanisms of reducing the brain drain through building local human resource development capacity and improving living and working conditions. Dialogue on mobilizing the Diaspora for brain drain by our countries should also be pursued with vigor, (Teshome, 2003).

This shows that the retention and attraction of bright academic staff, creative new comers and open channels for promotion seems to be the most challenging for the Ethiopian Ministry of Education (MOE) in general and for Universities in particular.

The core of the problem is a high movement (turnover and recruitment) among the academic staff, which is the most important input for the quality of education in a university (Wiswall, 2011). In other words, instructors are unexpectedly leaving the university and the university costs unacceptable size to replace them every year through recruitment, selection, training and socialization (AEE, 2007/8). Evidently, within the last four years (2010/11-2013/14), 216 academic staff members formally and voluntarily left the University. Moreover certain number of staff might have informally left the University. According to Meyer (2013); Killian (1976); Gomez-Mejia (2003), such a high turnover is always a symptom of a problem within an organization. Such excessive turnover can place current goal achievement of the university in 'jeopardy' (Meyer, 2013) because the operations of the university can be disrupted; the remaining teacher may be bored with extra load to cover the gap created by turnover and negatively affected by the feeling that there may be something wrong with the university or that there are better opportunities elsewhere outside the university; the future recruitment process of the staff in the university will be affected in that prospective candidate want to know why those former teachers left (Ingersoll, 2001/2). 


\section{Motuma Hirpassa Minda}

For these reasons, the main objective of the study is to identify the causes of turnover among the academic staff of Ambo University. Specifically, the study was to determine the magnitude of actual and potential turnover, assess the pushing and pulling factors among the academic staff of Ambo University and suggest some mechanisms and strategies to enhance among the academic staffs.

This study delimited to the causes (pushing and pulling factors) of turnover among academic staff of Ambo University. Pushing factors are also called controlled factors (Kainth, 2010; AEE, (2007/8) and Shah et al., 2010). These factors include: (1) economic factors (Inadequate Salary and Lack of Opportunities, such as advancement and fringe benefits), (2) managerial factors (poor performance evaluation and supervisory support, managerial violence and lack of transparence, equity, recognitions, unable to fit the competitive conditions between other organization, lack of power and job insecurity and other functions), (3) environmental Factors (physical hardships, temperature and location social and disadvantages), (4) technology and social services constraints (information communication, infrastructure and insufficient supply pure water, electric power etc), (5) teaching related factors (status of teaching, workloads, autonomy, recognitions, etc), (6) student character (disciplinary problems and deficient academic background (Loquercio, 2006 and Perlesz and Lindsay, 2003), and (7) the initial preferences of the university. On the other hand, according to Kainth (2010) and Shah, et al. (2010), the other round of these all factors are known as pulling factors (also called retention factors).
Sci. Technol. Arts Res. J., July-Sep 2015, 4(3): 285-293

\section{MATERIALS AND METHODS}

\section{Study Area}

This study was confined to Ambo University, which was established in 1946 and has recently become independent with a status of a university operating its functions currently with 5 colleges, 3 institutes and a school, which are also restructured into 39 undergraduate and 10 post graduate programs in various fields. The University envisions becoming a distinguished university in Eastern Africa advancing knowledge with a balanced approach to research and education towards human development, valuing professionalism, excellence and social progress. It is committed to attain its vision through the use of modern and environment friendly technology and the provision of quality service to its customer. In order to ensure this, the university strives to maintain a highly trained, motivated and dedicated workforce and enhance its internal capacity in various fields. In addition to the President and the two vice President offices, the University Administrative and Academic sections run by fifteen Directors.

\section{Sample Size}

A descriptive survey method was employed for its appropriateness to the nature of the topic as well as to collect and analyze data to investigate into the pulling and pushing factors that cause turnover of the academic staff members (Perlesz and Lindsay, 2003 and Shah, et al., 2010). Hence, the major sources of the data were both the current and the former instructors of Ambo University. Table 1 shows the population and sample size of current academic staff from each college.

Table 1: Population and sample size by college and qualification

\begin{tabular}{|c|c|c|c|c|c|c|c|c|c|c|c|c|c|c|c|c|c|c|c|}
\hline \multirow{2}{*}{ Colleges } & \multicolumn{3}{|c|}{ Diploma } & \multicolumn{3}{|c|}{ Bachelor } & \multicolumn{3}{|c|}{ M.D/MV } & \multicolumn{3}{|c|}{ Masters } & \multicolumn{3}{|c|}{ PhD } & \multicolumn{3}{|c|}{ Total } & \multirow{2}{*}{$\begin{array}{c}\text { Sample } \\
\text { Size }\end{array}$} \\
\hline & M & $\mathbf{F}$ & $\mathbf{T}$ & M & $\mathbf{F}$ & $\mathbf{T}$ & M & $\mathbf{F}$ & $\mathbf{T}$ & M & $\mathbf{F}$ & $\mathbf{T}$ & $\mathbf{M}$ & $\mathbf{F}$ & $\mathbf{T}$ & M & $\mathbf{F}$ & $\mathbf{T}$ & \\
\hline Technology & 36 & 3 & 39 & 84 & 8 & 92 & - & - & - & 61 & 1 & 62 & - & - & - & 181 & 13 & 194 & 59 \\
\hline Natural Science & 10 & - & 10 & 22 & 1 & 23 & - & - & - & 75 & 2 & 77 & 6 & - & 6 & 113 & 3 & 116 & 35 \\
\hline Medical & 4 & 1 & 5 & 28 & 5 & 33 & 20 & 5 & 25 & 44 & 3 & 47 & - & - & - & 96 & 14 & 110 & 33 \\
\hline Agriculture & 3 & 1 & 4 & 42 & 9 & 51 & 3 & 1 & 4 & 56 & 9 & 65 & 7 & 1 & 8 & 112 & 21 & 133 & 40 \\
\hline $\begin{array}{l}\text { Business and } \\
\text { Economics }\end{array}$ & - & - & - & 15 & 4 & 19 & - & - & - & 37 & 1 & 38 & - & - & - & 52 & 5 & 57 & 17 \\
\hline Social Sciences & - & - & - & 16 & 2 & 18 & - & - & - & 66 & 6 & 72 & 1 & - & 1 & 83 & 4 & 87 & 26 \\
\hline Law & - & - & - & 4 & 2 & 6 & - & - & - & 12 & 2 & 14 & - & - & - & 16 & 4 & 20 & 6 \\
\hline Education & 2 & - & 2 & - & - & - & - & & - & 27 & 1 & 28 & - & - & - & 29 & 1 & 30 & 9 \\
\hline Cooperatives & - & - & - & 2 & - & 2 & - & - & - & 21 & 3 & 24 & 1 & - & 1 & 24 & 3 & 27 & 8 \\
\hline Total & 55 & 5 & 60 & 213 & 31 & 244 & 23 & 6 & 29 & 399 & 28 & 427 & 15 & 1 & 16 & 705 & 71 & 776 & 233 \\
\hline Sample & 16 & 2 & 18 & 64 & 9 & 73 & 7 & 2 & 9 & 120 & 8 & 128 & 5 & - & 5 & 212 & 21 & 233 & 200 \\
\hline
\end{tabular}

There were 776 Ethiopian instructors in the university by the study time. However, 169(149 male and 20 female) of them were on study leave. Considering the size of the population, $30 \%$ (i.e. 6 to 59) of the current instructors (Cls) from each institute/colleges/school were proportionally selected based on the multiple stratified sampling techniques. Cascading to every department, two to seventeen respondents were proportionally selected from each department through systematic random sampling techniques using each department's attendance checklist. This made the total number of the respondents 233. The respondents were also stratified into the level of qualifications. Considering the qualification of the respondents, 18 (16 male and 2 female) Diploma, 73(64 male and 9 female) First Degree, 9 ( 7 male and 2 female) $\mathrm{MD} / \mathrm{MV}, 128$ (120 male and 8 female) Masters Degree and 5 male PhD holder instructors were selected for the study. On the other hand, within the last four years, more than 216 academic staff members formally and voluntarily left the University. As the result, available and snowball sampling techniques were employed to select 209 (197 male and 12 female) from 216 (104 male and 12 female) former instructors (FIs) of Ambo university because it was difficult to know where most of the former staff members were working by then. 
Motuma Hirpassa Minda

\section{Procedure of Data Collection and Analysis}

A triangulated data gathering approach, Questionnaire, interview and Focused group discussions, was used to gather the data for this study (Perlesz and Lindsay, 2003). Two different sets of attitudinal survey questionnaires were developed with 103 open-ended and 9 close-ended items using two different approaches to gather the data from current and former instructors. Thus, after pilot-testing process has been completed, 233 copies of the questionnaire were dispatched to, 212 male and 21 female, current instructors, and 209 copies of the other set of the questionnaire were dispatched to 197 male and 12 female former academic staff. However, 182 $(78 \%)$ of Cls, i.e. 167 male and 15 female current and 133 $(54 \%)$ of Fls, i.e.104 male and 9 female former academic staffs filled and gave the questionnaire back to the researcher. Particularly, the attempt to gather the data from the former instructors through e-mail was successful. To supplement the questionnaire, three different FGDs were held involving 30 current instructors from all the colleges/institutes/a school, and semi-structured interview was also employed with ten former and ten current instructors of the university. Besides, relevant documents from the university were used to secure relevant statistical information. Moreover the researcher has purposely used the teacher's conference held in the university during $30 / 9 / 2014$ to $09 / 10 / 2014$ to supplement the instruments.

The data were collected just before the salary increase was made on July 08, 2014. However, after the salary increase was made, data were collected from 10 key respondents for the second time to check whether, the salary increase has altered the tone of the previous data. Therefore, to make the discussions easier, the specific lists of the causes of the turnover are thematically organized into seven main topic and seventeen sub-topics considering their similarities and the kind of conditions in the study context (see table 4). Then, each of the final lists of the factors was composed of $10-15$ items with five options (strongly Disagree $=0$; Disagree $=1$; Undecided= 2 , Agree $=3$ and Strongly Agree $=4$ ) to which the respondents responded by putting a tick mark $(\checkmark)$. Finally, the data analyses were made employing both
Sci. Technol. Arts Res. J., July-Sep 2015, 4(3): 285-293

quantitative and qualitative approaches. Considering the data were ordinal and the wide gaps between the number of the group of respondents (current and the former staffs, male and female etc), frequency percentage, median, weighted mean, standard deviations, rank order and Mann Whitney $U$ Test were employed to compare the difference in level of attitude towards the pulling and pushing factors between different groups' responses. SPSS was used to calculate Mann Whitney U Test. For all statistical tests, alpha will be pre-set at $\alpha=0.05$.

\section{RESULTS}

The respondents were asked to indicate their age, marital status, level of salary and length of service years. The results indicate that $75(66.4 \%)$ of the $\mathrm{FI}$ were at most 30 years old, whereas only $95(52.2 \%)$ of the Cls reported that they were less than 30 years old. Moreover, the median age of the Cls was 34.7 and 29.7 was for Fls. According to the respondents, $116(63.7 \%)$ of the current and $73(64 \%)$ of the former instructors were married. The remaining instructors, in both cases, were unmarried during the time of this study. However, there is no data obtained on the divorced and widowed teacher in both cases. The Fls seem to have more work experience than the Cls because about $90(80 \%)$ of them have served at least for 10 years both in teaching and in non-teaching jobs while only $96(52.74 \%)$ of the Cls have similar service years. However, except in universities, the Fls particularly, those who were working for NGOs and embassies were earning better salary and income opportunities than the $\mathrm{Cls}$ with the same or less length of services years and level of qualifications.

\section{The Magnitude of Turnover among the Academic Staff of the University}

As already stated, 216 of instructors were left the university within the last four years, which means, 54 instructors every year. As a result, Ambo University has been compelled to employ 504 within the last four years, which means 126 per year, on average. The following figure 1 shows the voluntary turnover rate against the employed academic staff in the university by year.

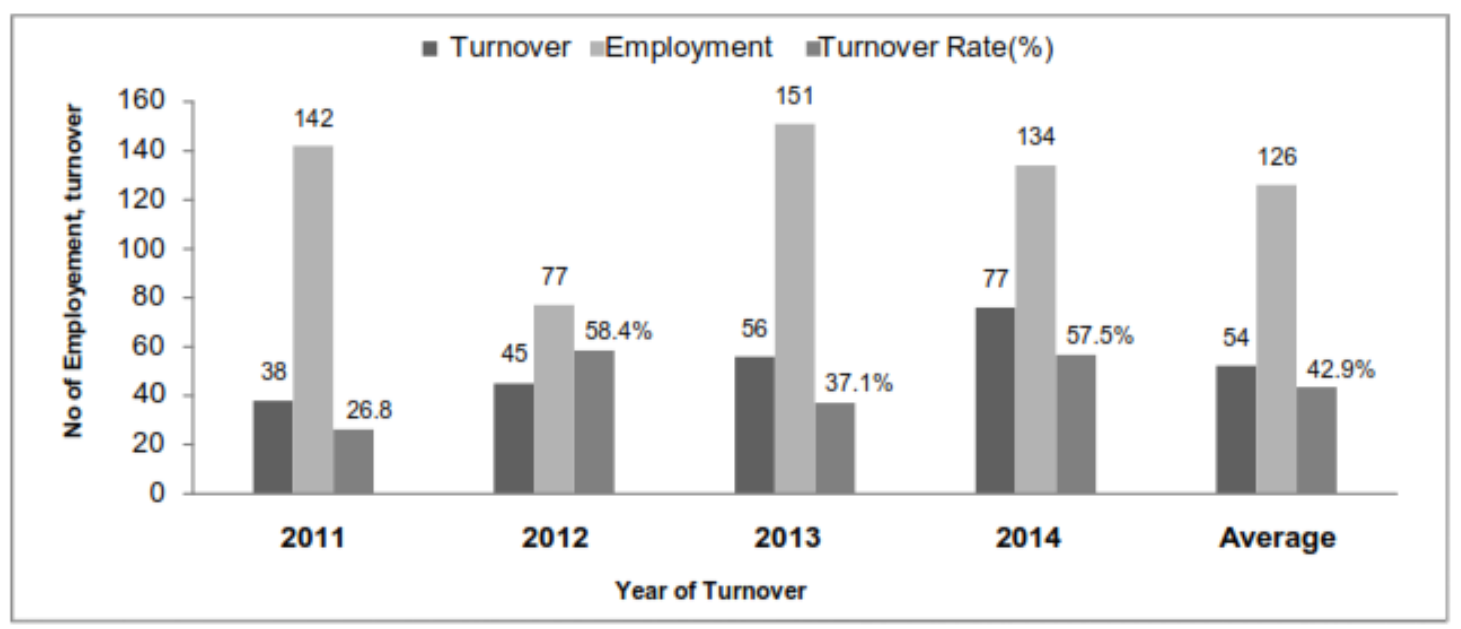

Figure 1: The dynamics of Academic Staff

The results show that the rate of average turnover among the hired instructors was $54(42.9 \%)$ within the last four years. It has been increasing from year to year that it was $38(26.8 \%)$ in $2010 / 11$ and $77(57.5 \%$ ) in $2013 / 4$.
Moreover, table 2 presents the magnitude of the actual rate of voluntary turnover among the total academic staff of Ambo University. 
Table 2: Turnover among academic staff College/Institute/School

\begin{tabular}{lcccccccccc}
\hline \multirow{2}{*}{\begin{tabular}{c} 
List of Institutions/Colleges/ \\
\multicolumn{1}{c}{ School }
\end{tabular}} & \multicolumn{3}{c}{ Present } & \multicolumn{3}{c}{ Turnover } & \multicolumn{3}{c}{ Turnover Rate } \\
\cline { 2 - 11 } & $\mathbf{M}$ & $\mathbf{F}$ & $\mathbf{T}$ & $\mathbf{M}$ & $\mathbf{F}$ & $\mathbf{T}$ & $\mathbf{M}$ & $\mathbf{F}$ & Total & Rank \\
\hline Cooperative and Development & 24 & 3 & 27 & - & 1 & 1 & - & 33.3 & 3.7 & $\mathbf{8}$ \\
Institute of Technology & 181 & 13 & 194 & 27 & 2 & 29 & 14.9 & 15 & 15 & $\mathbf{2}$ \\
Education and Professional & 29 & 1 & 30 & 1 & - & 1 & 3.5 & - & 3.3 & $\mathbf{9}$ \\
Social Sciences and Humanities & 83 & 4 & 87 & 19 & - & 19 & 21.8 & - & 19.5 & $\mathbf{1}$ \\
Natural and Computational Science & 113 & 3 & 116 & 8 & - & 8 & 7.1 & - & 6.9 & $\mathbf{5}$ \\
Business and Economics & 52 & 5 & 57 & 3 & 1 & 4 & 5.8 & 20 & 7.1 & $\mathbf{4}$ \\
Agriculture and Veterinary Sciences & 112 & 21 & 133 & 7 & 2 & 9 & 6.5 & 9.5 & 6.7 & $\mathbf{6}$ \\
Medicine and Health Science & 96 & 14 & 110 & 4 & 1 & 5 & 4.2 & 7.1 & 4.6 & $\mathbf{7}$ \\
School of Law & 16 & 4 & 20 & 1 & 1 & 2 & 6.3 & 25 & 10 & $\mathbf{3}$ \\
\hline Total & $\mathbf{7 0 5}$ & $\mathbf{7 1}$ & $\mathbf{7 7 6}$ & $\mathbf{7 0 6 9}$ & $\mathbf{8}$ & $\mathbf{7 8}$ & $\mathbf{1 0}$ & $\mathbf{1 1 . 3}$ & $\mathbf{1 0}$ & \\
\hline
\end{tabular}

The results show that the actual rate of turnover exceeds 10 percent by $2013 / 14$. The rate was $7.8 \%$ in $2010 / 11$; it was also increased to $10 \%$ in $20013 / 14$. The rate of turnover among the instructors in the College of Social Sciences and Humanities (19.5\%) was the highest. Moreover, Institute of Technology (15\%) and School of Law $(10 \%)$ respectively stood second and third in instructors turnover rate. However, Education and Professional Studies (3.3), Cooperative and Development (3.7) and Medicine (4.6), in ascending order, were the least in teacher turnover. Instructors in the institute of Education and Professional Studies reported that they have good income opportunities from different sources, such as CEP, and other training programs to supplement their salary. Therefore, what does this $10 \%$ actual voluntary turnover mean for Ambo University management body and for the remaining academic staff?

A $10 \%$ turnover rate in a team of academic staff implies different problems. On top of others, the management has to hire and train $10 \%$ new instructors within a year to replace the turnover. On average, among 126 instructors who were hired within a year, 54(42.9\%) instructors are hired to replace turnover in the university. The recruitment process to fill the gap that was vacated by turnover necessarily required both direct and indirect costs. Moreover, it has created the operational problems as the result of inexperienced staff (Ingersoll and May, 2012; Killian, 1976: 174; Gomez-Mejia 2003: 202). The potential turnover among the academic staff of the university was also estimated to be beyond $57 \%$.

\section{Dominant Sources of Turnover}

It is adequately documented that initial preference of an organization is one of the determinants of employees to leave or to stay in the organization. Cls and FIs of AU were asked to indicate why they come to teach in the university by ranking the five most important reasons from eight lists of reasons. The results show that most $235(58.75 \%)$ of the academic staff members had preferred to teach in Ambo University for its immense location advantages $(31.1 \%)$, its attractive weather condition $(3.8 \%)$ and its social advantages $14 \%$. Moreover, $59(14.8 \%)$ of the respondents had expected to get sufficient amount of money from none-salary sources like their friends in elsewhere universities. As a result, they $(58.75 \%)$ came to the university from other different higher institutions through the processes of transfer $(25 \%)$ and recruitment $(41 \%)$. However, a few $(20 \%)$ of them were assigned by the MOE without their interest. Similarly, a few $(9.8 \%)$ of them joined $A U$ to use it as stepping stone for their further education. The data on these issues were synthesized using weighted mean and frequency percentage in table 3.

Table 3: Summary of the Source of teacher Turnover and by Rank of Weighted Mean

\begin{tabular}{|c|c|c|c|c|c|c|c|}
\hline \multirow[b]{2}{*}{ No } & \multirow{2}{*}{$\begin{array}{l}\text { Source of Teacher } \\
\text { Main Topics }\end{array}$} & \multirow{2}{*}{$\begin{array}{r}\text { Turnover by Rank } \\
\text { Subtopics } \\
\end{array}$} & \multicolumn{5}{|c|}{ Mean and SDs by Rank ( $\mathrm{N}=295)$} \\
\hline & & & Mean & SDs & $\begin{array}{c}\text { Individual } \\
\text { Rank }\end{array}$ & Group Mean/SDs & $\begin{array}{l}\text { Group } \\
\text { Rank }\end{array}$ \\
\hline 1 & Initial Preference & Likes and Dislikes & 2.01 & 0.98 & 13 & 0.98 & 6 \\
\hline 2 & Economic Factors & $\begin{array}{l}\text { Salary } \\
\text { Promotion Opportunities } \\
\text { Compositions and fringe }\end{array}$ & $\begin{array}{l}3.36 \\
3.63 \\
3.82\end{array}$ & $\begin{array}{l}0.41 \\
0.24 \\
0.36\end{array}$ & $\begin{array}{l}7 \\
3 \\
1\end{array}$ & $\begin{array}{l}3.64^{*} \\
0.3+\end{array}$ & 1 \\
\hline 3 & Managerial Factors & $\begin{array}{l}\text { Performance Appraisal } \\
\text { Supervision Activities } \\
\text { Management Acts }\end{array}$ & $\begin{array}{l}3.32 \\
3.51 \\
3.62\end{array}$ & $\begin{array}{l}0.33 \\
0.21 \\
0.20\end{array}$ & $\begin{array}{l}8 \\
5 \\
4\end{array}$ & $\begin{array}{l}3.47^{*} \\
0.23+\end{array}$ & 3 \\
\hline 4 & $\begin{array}{l}\text { Socials services and } \\
\text { Technological Factors }\end{array}$ & $\begin{array}{l}\text { Technological Services } \\
\text { Social Services } \\
\text { Infrastructure }\end{array}$ & $\begin{array}{l}3.67 \\
3.50 \\
2.90\end{array}$ & $\begin{array}{l}0.48 \\
0.26 \\
0.43\end{array}$ & $\begin{array}{c}2 \\
6 \\
10\end{array}$ & $\begin{array}{l}3.57^{*} \\
0.78+\end{array}$ & 2 \\
\hline 5 & Environmental Factors & $\begin{array}{l}\text { Hardships } \\
\text { Temperature problems } \\
\text { Market prices }\end{array}$ & $\begin{array}{l}1.21 \\
1.13 \\
0.91\end{array}$ & $\begin{array}{l}0.12 \\
0.20 \\
.03\end{array}$ & $\begin{array}{l}15 \\
16 \\
17\end{array}$ & $\begin{array}{l}1.18^{*} \\
0.43\end{array}$ & 7 \\
\hline 6 & Teaching Related Factors & $\begin{array}{l}\text { Socio-economic status } \\
\text { Workload in AU }\end{array}$ & $\begin{array}{l}2.61 \\
2.11\end{array}$ & $\begin{array}{l}0.42 \\
0.31\end{array}$ & $\begin{array}{l}11 \\
12\end{array}$ & $\begin{array}{l}2.38^{*} \\
0.43^{+}\end{array}$ & 5 \\
\hline 7 & Students Characters & $\begin{array}{l}\text { Students Disciplinary } \\
\text { Students Academy }\end{array}$ & $\begin{array}{l}3.02 \\
1.99\end{array}$ & $\begin{array}{l}0.42 \\
0.21\end{array}$ & $\begin{array}{c}9 \\
14\end{array}$ & $\begin{array}{l}2.62^{*} \\
0.44+\end{array}$ & 4 \\
\hline
\end{tabular}

The ${ }^{*}$ and + refer to the overall mean, and SDs from higher to lower within the second box from the last. 


\section{Motuma Hirpassa Minda}

The results show that certain factors weigh more heavily in minds of the respondents than others. Hence, the study in general show that economic factors (3.64), social constraints and technological factors ((3.57), management factors (3.47), student characters (2.62), teaching related factors (2.38) and environmental factors (1.18) are, in descending order, perceived as the pushing factors by the academic staffs. Specifically, the results in the table show that money (composition opportunities and fringe benefits (3.82), lack of promotion opportunities (3.63), managerial acts (3.62) and social services constraints (3.60) are the first major concerns for the staff members. The next concerns for the instructors include technological services (3.57), poor supervision activities (3.51) inadequate salary (3.36), malcontented
Sci. Technol. Arts Res. J., July-Sep 2015, 4(3): 285-293

performance evaluation (3.32) and students' disciplinary (3.02). The results also show that infrastructure and facilities (2.90), socio-economic status attached to the profession (2.61), workload in the University (2.11), students' academic deficiency (1.99), Hardships (1.21), temperature problems (1.13) and market prices (0.91) are identified by the academic staff as the least pushing factors. The next section presents group differences on the level of dissatisfaction by Mann-Whitney $U$ Test among the factors.

\section{Group Differences}

The results of Mann-Whitney U Test on the rank order for group differences are summarized in table 4.

Table 4: Summary Data of Mann-Whitney U Test for Cls and Fls *

\begin{tabular}{|c|c|c|c|c|c|}
\hline \multirow{2}{*}{$\begin{array}{c}\text { The reasons for teacher turnover } \\
N=295(n 1=182+n 2=113)\end{array}$} & \multicolumn{2}{|c|}{ Weight Mean } & \multirow{2}{*}{$\begin{array}{c}\text { Sum of } \\
\text { Ranks }\left(R_{1}\right) *\end{array}$} & \multirow{2}{*}{$\mathrm{U}_{1}^{* *}$} & \multirow{2}{*}{$\mathbf{Z}$} \\
\hline & $\mathrm{FI}(1)$ & $\mathrm{Cl}(2)$ & & & \\
\hline In adequate salary and Promotions & 3.63 & 3.62 & 1515 & 25492 & 0.18 \\
\hline Social service and Technological & 3. 51 & 3.58 & 1608 & 25399 & 1.09 \\
\hline Inefficient Administration & 3.04 & 3.61 & 1445.5 & 25561.5 & $2.63^{++}$ \\
\hline Teaching Related Problems & 2.13 & 2.82 & 1549 & 25458 & $2.61++$ \\
\hline Students characteristics & 2.46 & 2.53 & 1437.5 & 25569.5 & $1.01^{++}$ \\
\hline Environmental Factors & 1.16 & 1.19 & 1506.5 & 25500.5 & 1.04 \\
\hline Initial Commitment & 1.46 & 2.61 & 4694 & 2496 & $2.12++$ \\
\hline
\end{tabular}

The standard deviations ranged for $0.35-0.60$ for CTs and from 0.26-0.49 for FTS. $++p<0.05$. * For brevity, only the sum of ranks for the smaller group is given here. The sum of ranks for the other group may be obtained by using the formula, $R_{2}=\left(n_{2}+1\right) n_{2} / 2-R_{1} * *$ $U_{1}=$ The number of times a FOGSSTs score precedes a COGSSTs Score $=n_{1} n_{2}+n_{1}\left(n_{1}+1\right) / 2-R_{1}$, where $n_{1}($ FOGSSTS $)=172$, $n_{2}=$ 193. For the other group, $U_{2}$ may be obtained by using the formula, $U_{2}=n_{1} n_{2}-U_{1}$.

The results of the study indicate that both current and former teachers felt dissatisfaction to a similar extent for the economic factors $(Z=0.18)$, student characteristics $(Z=1.01)$, Social service and Technological factors $(Z=1.09)$ and environmental factors $(Z=1.04)$. However, the current teachers showed greater concern about administration $(Z=2.63)$ and teaching status $(Z=2.61)$. In contrast former teachers showed more confidence to the availability of better employment opportunities (marketability of his/her personal skill) than the current teachers. A number of differences were also detected in the level of dissatisfaction between experienced teachers (with above 10 years experience) and less experienced teachers as presented in table 5.

Table 5: Summary data of Mann-whitney U Test for experienced and less experienced teachers*

\begin{tabular}{|c|c|c|c|c|c|}
\hline \multirow{2}{*}{$\begin{array}{l}\text { Reasons for the teacher turnover } \\
n_{1} *=131 \text { and } n_{2}=164\end{array}$} & \multicolumn{2}{|c|}{ Mean Scores } & \multirow{2}{*}{$\begin{array}{c}\text { Sum of } \\
\text { ranks }\left(R_{1}\right)\end{array}$} & \multirow{2}{*}{ U1 } & \multirow[b]{2}{*}{$\mathbf{Z}$} \\
\hline & Experi (1) & Less exper (2) & & & \\
\hline Inadequate Salary and Promotion & 3.71 & 3.53 & 16697 & 13432 & $2.42++$ \\
\hline Social service and Technological & 3.58 & 3.59 & 16723 & 13406 & 0.93 \\
\hline Inefficient Administration & 2.16 & 3.86 & 12442 & 17688 & $2.44^{++}$ \\
\hline Teaching Related Factors & 2.10 & 2.9 & 11773.5 & 18356.5 & $3.13^{++}$ \\
\hline Students' Characteristics & 2.4 & 2.69 & 17538.5 & 12591.5 & $2.29^{++}$ \\
\hline Environmental Factors & 2.39 & 2.41 & 12927.5 & 17202.5 & 0.94 \\
\hline Initial Commitment & 2.13 & 2.06 & 16774 & 12981 & 0.37 \\
\hline
\end{tabular}

The results of the study show that both the experienced and less experienced teachers were irritated with the constants interruptions of social and information communication services $(Z=0.93)$. Less experienced teachers demonstrated more sensitivity to the inefficient administration $(Z=2.44)$ and teaching related factors $(Z=3.13)$ in the university than experienced. These less experienced teachers feel greater dissatisfaction with regard to the management because they frequently blamed for maladjustment, poor teaching and other disciplinary problems.

On the other hand, experienced teachers are more dissatisfied with economic factors $(Z=2.42)$ than the less experienced. This is because experienced teachers with Masters and $\mathrm{PhD}$ degree are earning equal salary and other benefits with the less experienced, who have not yet begun challenging the too demanding requirements they need fulfill to get promotions. In other words, experienced teachers felt greater dissatisfaction with economic factors than the less experienced because of the fact that though initially the career structure promised considerable advantages for the experienced teachers, practically the rigorousness and the complexity associated with the promotion criteria have not adequately allowed that to happen, and the experienced teachers appear disillusioned. However, both groups indicated similar degree of dissatisfaction with poor income opportunities, performance evaluation and student unrests.

\section{DISCUSSION}

The weighted mean of the economic factors (3.64) is higher than any other pushing factors. The results show that $211(72 \%)$ of the respondents did not have hope about the salary promotion in general. Moreover, 231 


\section{Motuma Hirpassa Minda}

$(78 \%)$ of the respondents were dissatisfied with the lack of compensation or insufficient income (bonus, incentives and rewards for outstanding performance); fringe benefits and transport pay; field works' per-diem, sufficient research funds and insufficient part-time works to supplement their salary so as to meet their own financial needs and to support their family. On top of others, $162(89 \%)$ of the currents teachers were irritated with the amount of taxation particularly (35\%) due from their salary and, from house and position's allowances, CEP payrolls, adding on to the base salary. Besides, $228(77 \%)$ of the respondents were dissatisfied with the opportunities for career structure promotion in the university because very few instructors are achieving and using it to their financial goals they have set for themselves. Evidently, more than $90 \%$ of the instructors of Ambo University could not pass the too demanding criteria for promotion. Similarly, $235(79.7 \%)$ of the respondents feel that opportunities in $\mathrm{AU}$ to earn enough money is below what is expected by them at their level. That is why about $104(57 \%)$ of Cls decided to search an opportunity to change the university even for equal or less salary.

It was discouraging to listen to what teachers had to say on the teachers' conference held during 30/09/2014 to 09/10/2014 about their income opportunities and their hopes of regular salary increment (horizontal promotions) and their career structure (vertical promotion) by merit. Particularly, they complained that though the teachers' career structure has been set in legislation, it has been totally closed for most of the academic staffs. Discussing those economic factors, the result of this study is consistent with the findings of the earlier studies, Aklilu (1967) in that the highest and the weightiest reason for teacher turnover, the one stated most frequently was money, which has surprisingly been continued to be the most prominent pulling and pushing factors since 1953 to present in Ethiopia (Motuma, 2006). Moreover, the new salary scale in particular was not found to be significant predictor variable for the teachers satisfaction in the university.

Money is not the only reason for teachers leaving the university. Efficient clear decentralized management and effective supervisory activities are indispensable or absolutely essential for the teacher retention and quality education in university. However, weighted mean for managerial factors $(3.47)$ shows that the factors are the third most important pushing factors for the instructors. Specifically, about $73 \%$ of the respondents think that inefficient management is one of the serious reasons for the teacher turnover in the university. This is because, as to the $67.35 \%$ of the respondents, some management members are not actually sympathetic in their dealing with the teachers in university. The result of the study also shows that $186(63 \%)$ of the teachers claimed that they do not feel free to discuss their problems and claim their rights with some of the management members. Moreover, they do not think the management implements the laws to handle promotions and teachers assignments to different positions in fairways.

A process of the performance evaluation (PEP) of the teachers, which seems to be a slippery task in the university, does nothing for the academic staff. In other words, though basically performance evaluation is important to determine how well employees do their jobs, most $(89 \%)$ of the respondents think that it has no
Sci. Technol. Arts Res. J., July-Sep 2015, 4(3): 285-293

contribution to either advancement or demotion. According to $50 \%$ of the respondents, the process and the criteria of the performance evaluations do not seem to be independent of the evaluators' bias and hearsay. Moreover, most $(79 \%)$ of the respondents think that PEP for career structure promotion includes some too demanding and confusing criteria (a number of research publications and community development) to interpret and implement. Moreover, most $(90 \%)$ of the teachers in the university do not know why they are asked to prepare $\mathrm{BPR}$ and BSC to be evaluated with. In their BSC, the teachers think that they are forced to include more nonteaching activities than instructional activities.

Most $(86 \%)$ of the respondents also complained that the teachers' PEPs do not involve transparency as per the policy set because the candidates could not get complete information and use the result of their appraisals for promotion and self-improvement, as well as challenge the evaluators in cases of faulty judgments. Concerning the evaluators, participation of students, peers, and the head of the respective department is helpful to increase the reliability and validity of the evaluation results if and only if the evaluators know why and what they evaluate because almost $90 \%$ of the respondents reported that they face difficulties to evaluate their peers at the absence of specific and dependable information about the achievements of their peers to give fair treatment. Consequently, the finding of the present study is in line with the findings of Masahudu (2008), Khan, et al., (2012), Victor, Pertunia and Machaisa, (2012) and Wiswall, (2011) in that confusions as a result poor PEP affected the teachers' morale.

The respondents frequently listed that although teachers have basically been considered as 'scapegoats', who are responsible for all sins committed even by others, the values given for the teacher are less than the effort that $\mathrm{s} / \mathrm{he}$ has to exerts. Evidently, the weighted mean of the teaching related factors (2.38) shows that the teachers are not provided with a better deal of values than they could get by working for alternative organization. Specifically, the summary of the mean scores of the responses of the respondents indicate that perceived low socio-economic status (3.34), lack of recognition (3.12) and lack of professional autonomy (3.01) are ranked 1to 3 , respectively, on the rank order as sources of teachers' dissatisfaction. Scapegoat means a teacher is 'all'. Teachers are normally responsible for economic, political and social crises of a country. The logic is to express that if teachers do not properly play their appropriate roles, nothing can go right.

The analyzed using the weighted mean (1.18) shows that the environmental factors are the most important pulling factors for the academic staff of the university. These factors are categorized into environmental hardships (1.21), temperature problems (1.13) and market prices $(0.91)$. The result specifically shows that most $235(58.75 \%)$ of the academic staff members had preferred to teach in Ambo University for its immense location advantages (31.1\%), for its attractive weather condition(3.8\%) and for its social advantages (14\%). Most instructors $(68 \%)$ identified Ambo University as an "ideal place" for them among the universities in Ethiopia. As a result, they $(58.75 \%)$ came to the university from other different higher institutions through the processes of transfer $(25 \%)$ and recruitment (41\%). 


\section{Motuma Hirpassa Minda}

Paradoxically, according to the respondents, the challenges external to the university disrupted the instructors' retention rather than the internal ones. The weighted mean (3.57) of the factors show that the social service constraints and technological factors are the second most important pushing factors for the academic staff of the university. These factors are categorized into social service problems (3.60) technological factors (3.67) and lack of infrastructure and facilities (2.90). The results show that $193(65 \%)$ of the respondents are negatively affected by the of social services the problem such as the substantial interruptions of pure water and of electric power supply, poor access to information through telecommunication and internet services are identified as sources turnover. Similarly, the respondents mentioned that personal and office facilities in the university were also identified as the source of teacher dissatisfaction in the university. Moreover 96 (33\%) of the respondents have reported that the problem of health service in the area is another pushing factor.

The weighted mean (2.62) shows that the students' character in the universities is identified as a source of disappointment for the teachers today. Student characters were categorized into two: students' disciplinary problems (3.02) and deficient academic background (1.99). The findings show that 114(38.6) of the respondents reported that they were frustrated by the students' disciplinary problems in the university. Similarly, $140(47.5 \%)$ of the respondents think that students' arrogance due to their status as evaluators of teachers' performance contributes to teacher dissatisfaction. Moreover, 132(44.7\%), $199(67.5 \%)$ and 136(46\%) of the respondents think that students absenteeism, unrest and disregard for doing homework, respectively affect teachers retention in the university. Students' deficient academic status does not seem to be a serious problem and cause for teacher turnover. Although it is not a serious problem, the calculated mean scores and standard deviations show that large class size (1.2), deficiency in English language 1.8) and low motivation of some students to learn (1.9) are identified as sources of turnover.

In general, most of the findings of this study are consistent with the results of some studies conducted in other sites in Ethiopian by Aklilu (1967), Getachew (1999), Manana and Tesfaye (2000), Darge (2002) Tesfaye and Demoz (2004) and Motuma (2006) in that initial preference, economic factors, social constraints and technological factors, management factors, student characters, teaching related factors and environmental factors are in different order, identified as the sources of turnover among the academic staffs. The result of this study is also found to be in line with the findings identified by Ingersoll and May (2012) in that teachers usually calculate their benefits to get job that better meet their career needs elsewhere outside the university.

\section{CONCLUSIONS}

On the basis of data analysis made so far, the actual rate of voluntary turnover for the university teachers has been increasing from year to year; it exceeds $10 \%$ in $2013 / 14$. To replace the turnover, the university has to recruit $54(43 \%)$ instructors every year, and it was above $77(57.5 \%)$ in 2013/4. In addition, the actual rate of turnover for the fresh teachers, who left within one year was about $21(16 \%)$ within the last four years. Migration is
Sci. Technol. Arts Res. J., July-Sep 2015, 4(3): 285-293

the most serious component that accounts about more than half of the overall teacher turnover among the university academic staff. Moreover, the potential rate of turnover among the academic staff in the university exceeds $57 \%$. Similarly, male, experienced, Masters Degree holder teachers in College of Social Science, Institute of Technology and School of Law in descending order tend to leave the university at higher rate than their counterparts.

Surprisingly, the economic factors are perceived as both pulling and pushing factors by the academic staffs of the university. That is, initially most of the teacher had expected Ambo University as a better source of income opportunities to earn sufficient income particularly from non-salary sources. In contrary to their expectation, the weightiest reason for teacher was money, i.e. opportunities for promotions and fringe benefits, special financial and material rewards, and incentives for outstanding performance outside the university has altered the preference of and commitment to the university over others. However, most of the young and less experienced teachers show greater satisfaction with the current salary scale. In opposite, social and technological service constraints, managerial, environmental, Student characters and the teaching related factors in descending order are identified as main pushing factors of the academic staff of the university. However, most of the managerial factors, which are frequently listed as pushing factors, are related to the government policies and regulations rather than institutional implementation problems. Moreover, some of the economic problems are the results of the failure of the university management to create some sources of income opportunities, e.g. sufficient CEP and research funds etc.

The straight forward answer to the question of how best to retain teachers in the university is to provide them with a better deal, in the broadest sense, than they could get by working for alternative organizations. In other words, as the quality of an educational program implementation depends strongly on the quality of academic staff, programs must be designed, initiated, administered, monitored, and changed to retain this valuable human resource asset. For this end, the government, ministry of education and university should work together to improve poor opportunities in the universities and other benefit inequalities between universities and others?

The results of the study also implies that turnover among the university academic staff is a function of the institutional administrative factors. As the result, the University management should ensure that all its sections (the technical level leaders) are democratic, facilitative, and sympathetic with employees and are doing to maintain equity, recognition and democratic leadership fostering transparency, increasing participatory decisions and professional autonomy to maintain teachers' confidence on the management and job security in the university. The University management should ensure the expansion and implementation of CEP and research fund, availability of personal facilities/office furniture and social services. Management also needs to give workshops and trainings on BSC and BPR to avoid confusions. Moreover, government, university management, teachers, students religious leader and other stakeholders should work together to seek ways to inhabit students' unrests and 


\section{Motuma Hirpassa Minda}

improve the scarcity of infrastructure and social service (network, internet services, water and electricity supplies) in Ambo.

\section{Conflict of Interest}

Conflict of interest none declared.

\section{Acknowledgements}

I sincerely acknowledge Dr. Tesfaye Balemi and Mr.Ebrahim Hamza for their unreserved support.

\section{REFERENCES}

Aklilu Habte (1967). Brain Drain in the Elementary School: Why Teaches leaves the Profession. The Ethiopian Journal of Education 1(1): 32-54.

Alliance for Excellent Education (AEE), (2007). Teacher Turnover Could Cost U.S. \$5 Billion Annually. Washington, DC: Issue Brief, Pp. 34-36.

Alliance for Excellent Education (AEE). (2008). What Keeps Good Teachers in the Classroom? Understanding and Reducing Teacher Turnover. Issue Brief, Pp.54-58

Asif, M., Khan, S. and Shahzd, S. (2012). The influence of Push, Pull and Personal Factors on Employees Turnover. Interdisciplinary Journal of Contemporary Research in Business 3(12): 1-10.

Bame Kewabena, N. (1991). Teachers Motivation and Retention in Ghana. Accra: Ghana University Press, 213267.

Belkin, L. (2013). Employee Turnover: Push Factors and Pull Factors: The Opt-Out Revolution. The New York Times. $1-11$

Brinson, D. and Rosch, J. (2010). Charter School Autonomy: A Half-Broken Promise. Washington, D.C.: Thomas B. Fordham Foundation. Pp. 24-58.

Darge Wale (2002). The pre-determinants of Difference Sources of Stress Among Teachers in Government Senior High Schools of Addis Ababa. The Ethiopian Journal of Education XXII(1): 34-65.

Ellenburg, F.C. (1979). The Factors Affecting Teachers Moral in Frances Griffith(ed). Administrative Theories in Education. Michigan: Pend I Publishing Company.Pp.4969.

Getachew Haile (1999). Stress in School Teachers. The Ethiopian Journal of Education XIX(2): 51-72.

Ghaffari Hadi and Singh, S.P. (2000). Pull-Push Determinants of Inter-Provincial Migration: Iran's Case Study. Indian Journal of Economics 81(321): 269-275.

Gomez-Majia, L.R. (2003). Managing Human Resource. $\left(3^{\text {rd }}\right.$ Ed).New Delhi Prentice Hall of India Private Ltd. 105-289.

Guzma D. Mylena (2012) Push-pull Factors Affecting Teachers Retention in Metro Manila University. University of Philipin, Dilman. Pp.81-102.

Harris, D. (2007). Should I Stay or Should I Go? Comparing Teacher Mobility in Florida's Charter and traditional Public Schools. Peabody Journal of Education 82(2-3): 274-310.

Hill, Alexandra and Hirshberg Diane (2013). Alaska Teacher Turnover, Supply, \& Demand: Education Policy Research: University of Alaska Anchorage, UAA Center for Alaska. http://epa.sagepub.com/content/34/4/435, Pp.35-55

Ingersoll, R. (2001). Teacher Turnover \& Teacher Shortages: An Organizational Analysis. American Education Research Journal 38(3): 499-534.

Ingersoll, R. (2002). The Teacher Shortage: A Case of Wrong Diagnosis and Wrong Prescription. NASSP Bulletin 86: 16-31.
Sci. Technol. Arts Res. J., July-Sep 2015, 4(3): 285-293

Ingersoll., Richard, M. \& May Henry (2012). The Magnitude, Destinations, and Determinants of Mathematics and Science Teacher, University of Pennsylvania. Pp. 56-79.

Nias Jennifer (1981). Teachers Satisfaction \& Dissatisfaction: Hertzberg's Two-factor' Hypothesis Revised. British Journal of Sociology of Education 2(3): 24-42.

Kainth, G. Singh (2010). Push and Pull Factors of Migration: A Case Study of Brick Kiln Migrant Workers in Punjab, http://mpra.ub.uni-muenchen.de/30036/, 12. Feb 2013

Killian Ray. A. (1976) Human Resource Management: An ROI Approach. AMACOM, Pp. 12-29

Loquercio, D. (2006). Turnover and Retention. Retrieved 02 01, 2014, from People in Aid: www.peopleinaid.org

Manna Olango and Tesfaye Semela (2000). Determinants of Teachers Decision to Leave or Stay in the Teaching Profession. The Ethiopian Journal of Education XX(1).

Masahudu, G. (2008). Why it is Difficult to Retain Employees? Retrieved 12 10, 2013, from Why Retain Employees?:http://knol.google.com/k/osman-masahudugunu/why-it-is-difficult-to-retain employees/

Meyer Leila (2013). Teacher Turnover Negatively Impacts Student Achievement in Math and English. URL: http://thejournal.com/articles/2013/07/29/teacherturnover-negatively-impacts-student-achievement-inc. 99

Motuma Hirpassa (2006). A Study on Causes of Teacher Turnover in Oromia Government Secondary Schools. (Unpublished Master's Thesis), Addis Ababa University, College of Education. Pp.76-113

Paulse J. (2005). Sources of Occupational Stress for Teachers, with Specific Reference to the Inclusive Education Model in the Western Cape. Master Atrium' thesis: University of the Western Cape. Pp, 1-9.

Perlesz, A. and Lindsay, T. (2003). Methodological Triangulation in research families: Making Sense of Dissonant. International Journey of Social Research Methodology 6: 25-40.

Seyoum Tefera (1992). Brain Drain Among Academissians in Two Higher Education Institutions in Ethiopian. The Ethiopian Journal of Education 13(2): 25-40.

Shah, I. A., Fakher, Z., Ahmad, M.S. and Zaman, K. (2010). Measuring Push, Pull and Personal Factors Affecting Turnover Intention. A Case Study of University Teachers in Pakistan . pp. 401-410

Smith, T.M., and Rowley, K.J. (2005). Enhancing Commitment or Tightening Control: The function of teacher professional development in an era of accountability. Educational Policy 19(126) (\#1, 5, 7.2).

Taylor, Stephen (1998). Employee Resourcing. Wiltshire: The Cromwell, Great Britain, Pp. 134-160.

Tesfaye Semela and Demoze Admasu (2004). Begninnig Teaches Education Students Attrition Tewardstheir Future Professio: the Case of Dilla university College $f$ Teacher Education and Health Science. The Journal of Education XXIV(1): 65-90.

Teshome Yizengaw (2003). Transformations in Higher Education: Experiences with Reform and Expansion in Ethiopian Higher Education System. Keynote paper at conference Improving Tertiary Education in Sub-Sahara Africa: Things that Work. Ghana, Accra, Pp. 1-36

Victor, J. Pitsoe., Pertunia, R. Machaisa. (2012). Teacher Attrition Catastrophe in Sub-saharan Africa: A Hurdle in the Achievement of Upe, Efa Policy Goals and Mdgs. Science Journal of Sociology and Anthropology 20-12.

Wiswall, M. (2011). The dynamics of Teacher Quality. Retrieved from: http://www.aefpweb.org/sites/default /files/webform/wiswall teacher dynamics.pdf 